\title{
Problems and Suggestions on the Implementation of Mixed-ownership Schooling in Higher Vocational Colleges
}

\author{
Kai Liu*, Wen Zhou and Boru Yang \\ ( Yunnan Foreign Affairs and Foreign Languages Vocational College, Yang Lin 651700)
}

Keywords: The Mixed Ownership, Higher Vocational Education, The School Model Online

\begin{abstract}
Although the mixed ownership system in higher vocational colleges in China has just started, the mixed ownership system has gradually matured. The mode of mixed ownership of higher vocational colleges will surely become more and more mature, while the mixed ownership system in higher vocational colleges will have many problems and defects. This paper presents the problems existing in the running of mixed-ownership vocational colleges and the corresponding countermeasures, aiming to provide a reference and suggestions for the mixed system of vocational colleges in China.

On February 26, 2014, Premier Li Keqiang proposed to speed up the development of modern vocational education in the State Council executive meeting. In the same year, the State Council's "Decision on Accelerating the Development of Vocational Education" of the State Council on May 2, the State Council pointed out: "To explore the development of joint-stock and mixed-ownership vocational colleges and allow them to participate in running schools with capital, knowledge, technology, management, and other relevant rights. To explore the mechanisms for the mutual management and purchase of services by vocational colleges run by public and social forces. To guide social forces to participate in the teaching process and jointly develop curriculum and teaching materials." Vocational colleges organized by social forces enjoy the same legal status as public vocational colleges and relevant education, fiscal and taxation, land, and finance policies. The country will improve the system of government subsidies, purchase of services, student loans, fund awards, and incentives for donations, and encourage social forces to participate in the running, management, and evaluation of vocational education."
\end{abstract}

\section{Overview of Mixed Ownership}

At the Party's 15th National Congress, the term "mixed ownership", an economic domain term, entered the public for the first time. It is believed that the socialist public ownership economy includes not only the state-owned economy we generally understand, but also the state-owned and collective components of the mixed ownership economy. The Third Plenary Session of the 18th CPC Central Committee makes it clear that it is necessary to take active measures to develop mixed-ownership economic measures and establish a mixed-ownership economy with cross-shareholdings, such as state-owned capital, collective capital, and non-public capital. For the first time, a mixed-ownership economy is a basic economy. "An important form of institutional realization" allows more state-owned and other ownership economies to develop into a mixed-ownership economy.

\section{Mixed Ownership System of Higher Vocational Colleges}

The connotation of the mixed ownership higher vocational colleges is to attract various forms of social capital, such as capital, knowledge, technology, management, and equipment, and to participate in investment in schools in accordance with the principles of win-win benefits and risk sharing. The structure of the school's property rights has undergone revolutionary changes. It has been transformed from a state-owned single-ownership school to a new-type school subject whose economic entities of different ownerships jointly invests and jointly implements decision-making, evaluation, and improvement. Mixing all institutions Higher education institutions are essentially education modes organized by joint ownership of shares in different forms of ownership. Higher 
education is carried out by enterprises and the market forces are used to promote the development of higher vocational education. The essential feature of the mixed-ownership vocational colleges is to achieve the optimal allocation of production factors through the mixture of property rights subjects and governance structures, so that different property right entities can penetrate and merge into a new interest community.

\section{Problems in the Implementation of Mixed-Ownership Schooling in Higher Vocational Colleges}

\section{Policies are Not Well Understood}

The concept of blending all systems is not well understood. For example, the joint stock system is not necessarily a mixed system, but the mixed system is a special form of shares. Higher vocational colleges have few contacts with the vocational education policies jointly organized by the government and the society, and they do not have thorough understanding. They do not fully understand the reforms of mixed-ownership schooling. At the same time, the state does not have sufficient publicity for successful mixed-owned school schools and the summary is not in place. Therefore, many higher vocational colleges do not have more experience to learn from.

\section{Property Rights Are not Clear}

The current public vocational colleges strictly implement the state-owned assets management system in the management of state-owned assets. This is a guarantee for the preservation and appreciation of state-owned assets and non-disposal. However, at the same time, public institutions cannot become shareholders of any economic entity and cannot carry out assets. The rules governing business activities hinder the exploration and practice of public institutions to rely on their own strength for sustainable development. Publicly-owned colleges and universities' assets cannot be used as they should be, while intangible assets are at risk of being lost. These state-owned assets do not have the opportunity to be used effectively according to the laws of the market. In the long run, public vocational colleges can only rely on government funding as the main channel for development, lacking self-hematopoietic function. It is difficult to form a sustainable development mechanism.

\section{Management Responsibilities are not Clear}

The mixed ownership system is a new model for the running of higher vocational colleges, and the corporate governance structure is a new attempt based on the innovation of mixed ownership education. There is bound to be an irreconcilable contradiction in the implementation of enterprise management in the new mode of running higher vocational colleges. After all, schools are not enterprises. They cannot use enterprise concepts to manage school teachers. They cannot accept the principal responsibility system under the leadership of the school party committee. Enterprises cannot accept it. This is essentially different from corporate governance structure. The support of the policy system is not in place. The government and education authorities sometimes take a wait-and-see attitude, which will result in the loss of state-owned assets or educational corruption. Even the confusion of school management and teaching management will become unclear.

\section{Suggestions for Promoting the Development of Mixed Ownership in Higher Vocational Colleges}

\section{Establish Sound Laws and Regulations, Strengthening Policy Guidance}

Mixed ownership higher vocational colleges run as a new thing, and there is still lack of laws and regulations that are suitable for them. It is necessary to publish as soon as possible guidance from the State on pilot projects for mixed-ownership vocational colleges. According to the existing laws, based on the "State Council's Opinions on the Development of Mixed-ownership Economy in State-owned Enterprises," the education administrative department, together with relevant departments, should formulate a unified guidance on the exploration of mixed-ownership education reform as early as possible. $\mathrm{n}$ the past few years, the "People's Republic of Education Law," "The People's Republic of China Higher Education Law," and the "Law of the People's Republic of China 
on the Promotion of Private Education," have been revised, but they still exist in asset management, property rights protection, profit distribution, and education. Problems such as risk prevention and withdrawal mechanism lack legal and policy basis, and clearly define the nature of mixed-owned vocational colleges. To fundamentally attract and mobilize all social forces to participate in school running and enthusiasm, it is necessary to accelerate the formulation of laws and regulations that are suitable for the development of mixed-ownership vocational colleges.

Mixed-ownership vocational colleges can better conduct school-enterprise cooperation only on the initiative of the local government or the competent authorities, and deepen the mode of joint-stock education, new teacher preparation structure, clear property rights, and risk optimization. It can well absorb social funds to participate in school in a flexible way.

\section{Building a Platform for Resource Integration}

Resources such as funds, technology, and teachers are important factors that restrict the development of schools. Especially when higher vocational colleges receive less and less support from state policies and capital subsidies have been declining year by year, schools must broaden their resource channels. In this period, the Chinese government will give full play to its functions. The government can lead the distribution of schools' equity and the separation of interests, as well as help vocational colleges to establish vocational education groups, encourage vocational colleges to develop school-run enterprises, use the government to absorb social funds, encourage social donations, and so on. The government sets up a platform for resource integration for mixed-owned vocational schools.

\section{Improving the New Management System}

In order to avoid irreconcilable conflicts between enterprises and institutions, it is necessary to establish a new type of sound management system: clarify responsibilities, establish and improve the management system, and perform their duties; then set up the corresponding supervision and assessment team to regularly improve the mixture of all systems. Vocational colleges carry out administrative supervision so as to form a management system with distinct layers, upward effectiveness, and clear responsibilities; the last is to improve the social supervision system so that the government, society, enterprises. Schools can develop vocational colleges under escort and supervision.

\section{Establishing a New Teacher Preparation System}

Mixed ownership higher vocational colleges should implement two types of new employment system for the development of coexistence and development. The teacher of the business establishment can enjoy the equity incentive or equity of the company and the end-of-year dividend bonus. The teacher of the contract system can also enjoy the teacher's professional title assessment, the post-retirement and enjoyment of the job promotion, and the establishment of a certain retirement benefit. Only in this way, can teachers be unified in their management, and teachers' enthusiasm for work should be increased. This will lay a good foundation for the establishment of a new salary for equal pay for equal work and a new teacher preparation. As early as the beginning of this century, mixed ownership institutions have already made attempts in China. Enterprises and other capitals have participated in the running of higher vocational schools, which is conducive to enriching the mode of running higher vocational schools, solving the shortage of government funds, and optimizing the allocation of resources. However, the real implementation of the mixed ownership system across the country is still in its infancy. There are still many defects and problems in the school-running mode, professional setting, etc. In the 2014 government work conference, the mixed ownership system was formally adopted as a new idea and method for the development of higher vocational colleges. Although the mixed ownership system of higher vocational colleges in our country has just started, the mixed ownership system has gradually matured. The mixed ownership system of higher vocational colleges will surely become more and more mature, and the mixed ownership of higher vocational colleges will eventually become higher vocational education. The mainstream of the school-running mode of the colleges and universities and the advantages of the university's school cooperation have enabled the further development of the running of higher vocational schools in China. 


\section{Acknowledgement}

This article was funded from the Scientific Research Project of the Yunnan Provincial Department of Education. Teacher's Question: Theory and Practice of Mixed-ownership Higher Vocational Colleges, Subject No. 2018JS874

\section{References}

[1] State Council. Decision on Accelerating the Development of Modern Vocational Education [Z]. Guofa [2014] No. 19, 2014-5-2.

[2] Xiao Weiping, Yao Xiaobo. Research and Practice on Institutional Innovation of Mixed-ownership Schools in Vocational Colleges[J].China Vocational and Technical Education.2016(7)

[3] Zhong Na. Research on the Legal Problems of Public-owned Higher Vocational Colleges Implementing Joint-stock (Mixed Ownership) Schools [J].

[4] Wu Yiqun, Fan Kexu. Exploration on the Research and Exploration of the Reform of Mixed-ownership Schooling in Higher Vocational Colleges [J].Education and Occupation.No.9 (total 865)

[5] Liao Chengliang. Problems and Countermeasures of Mixed-ownership Schooling in Higher Vocational Colleges in Liaoning Province. Shenyang Normal University Master's Dissertation.

[6] Xie Jun. Problems in the implementation of mixed ownership system in higher vocational colleges and their countermeasures [J].Education Modernization.2016.38.156

[7] Liu Jiashu. Mixed Ownership: The Path and Mode of Deep Integration of Production and Education in Higher Vocational Colleges [J]. Theory, Latitude, Longitude, Vocational Education Forum, 2015.4

\footnotetext{
About Author

Kai Liu(1983-)Inner Mongolia root river city person, Associate professor, postgraduate, Assistant dean of foreign foreign language vocational college of yunnan, Mainly engaged in teaching management, 649601243@qq.com。

Wen Zhou(1974-) Chongqing people, Research assistant, postgraduate, Teacher of yunnan foreign language vocational college, Mainly engaged in ideological and political education,

249773193@qq.ocm。

Boru Yang(1989-)female, Hebei Tang Shan, master graduate student, lecturer title, research direction: human resources management, organizational behavior, economics of education, 945211931@qq.ocm.
} 